\title{
Menstrual Cycle Dependent Variability for Serum Tumor Markers CEA, AFP, CA 19-9, CA 125 and CA $15-3$ in Healthy Women
}

\author{
Ayşe Binnur Erbağci ${ }^{1, \#}$, Necat Yilmaz ${ }^{1}$ \\ and Irfan Kutlar ${ }^{2}$ \\ ${ }^{1}$ Department of Biochemistry and Clinical \\ Biohemistry, Faculty of Medicine, University \\ of Gaziantep, Gaziantep, Turkey \\ ${ }^{2}$ Department of Obstetrics and Gynecology, \\ Faculty of Medicine, University of \\ Gaziantep, Gaziantep, Turkey
}

\begin{abstract}
Information on menstrual cycle dependent variation of tumor markers in healthy women is a subject of diagnostic efficiency and has an impact in elucidating the normal function of these markers. In this study midfollicular and midluteal concentrations of serum CEA, AFP, CA 19-9, CA 125, CA 15-3 and their relations with LH, FSH, prolactin, estradiol and progesterone were evaluated during ovulatory cycles in a group of 23 healthy female individuals. Samples were collected on the $7^{\text {th }}$ and $21^{\text {st }}$ day of the same menstrual cycle. Tumor marker and hormone concentrations were determined with chemiluminescence or electrochemiluminescence EIA methods. A significant phase-dependent difference was observed for CA 15-3, midluteal concentrations (mean $\pm \mathrm{SEM} ; 26.33 \pm 1.56 \mathrm{U} / \mathrm{ml}$ ) higher than the midfollicular (mean \pm SEM; $19.27 \pm 1.49 \mathrm{U} / \mathrm{ml})$ concentrations $(\mathrm{p}<0.001)$. But an obvious difference for other tumor markers investigated did not exist. Significant correlations of follicular and luteal CA 125 levels with body mass index of the subjects were observed (r:0.52, $\mathrm{p}<0.05$ and $\mathrm{r}: 0.57, \mathrm{p}<0.005$, respectively).
\end{abstract}

\footnotetext{
${ }^{\#}$ Correspondence: Dr. Ayşe Binnur Erbağc1, Department of Biochemistry and Clinical Biochemistry, Faculty of Medicine, University of Gaziantep, TR-27310 Gaziantep, Turkey, Tel.: +90342360 1200-3203, Fax: +90 342360 1617, E-mail: erbagci@gantep.edu.tr
}

CA 15-3 antigen is a product of the MUC-1 gene which is expressed in abundance by endometrial epithelial cells in the secretory phase of the menstrual cycle which may be the potential source of variability. The association of CA 125 levels with obesity suggests a possible role of adipose tissue in CA 125 metabolism. In conclusion our data suggest that in healthy women serum CA 15-3 levels are significantly elevated in the midluteal phase of the menstrual cycle compared to midfollicular phase. Therefore, consideration of menstrual cycle dependent variability for CA 15-3 appears indicated in interpretation of individual results.

KEYWORDS: Tumor markers, menstrual cycle, CEA, AFP, CA 19-9, CA 125, CA 15-3

\section{INTRODUCTION}

The most important function of laboratory tests in cancer is detecting recurrence or monitoring progression of the malignant disease and its response to therapy. Screening, confirming and classifying are other possible roles $[21,23,25]$. Biological variability of serum tumor markers creates difficulties in evaluation of serial data and limits reliability of reference ranges, thus decreasing specificity and sensitivity $[19,24]$.

In women there is a closely coordinated interplay of feedback effects between pituitary gonadotropin and ovarian steroid secretion during the menstrual cycle. Follicular phase is characterized by relatively high concentration of follitropin (FSH) and low concentrations of lutotropin (LH), estradiol and progesterone. During the ovulatory phase, there is a rise in estradiol, LH and FSH levels that is followed by 
ovulation. In the luteal phase concomitant with the abrupt decrease in LH, serum estradiol falls precipitously and progesterone increases. During this period other peptide hormones and growth factors are also secreted. These cyclical hormonal changes lead functional and structural changes in the ovaries, endometrium and mammary glands. Monthly fluctuations of many other analytes related to this cyclical variation are observed, corresponding to the time of secretion of these hormones [30]. A possible influence of physiological monthly variation of hormones on release and elimination of tumor markers in healthy females is a subject of diagnostic efficiency even if all of the individual results lie within the current reference range.

CA 15-3 is a breast associated antigen encoded by the MUC-1 gene. The human MUC-1 gene codes for the core protein of a mucin which is expressed by glandular epithelia and carcinomas which develop from these tissues. Monoclonal antibodies reactive with these molecules define a difference in the mucin derived from normal and cancer tissues. It is now clear that this difference lies in the carbonhydrate side chains. The core protein is aberrantly glycosylated in cancers resulting in appearance of novel epitopes [9, 14,18]. CA 15-3 antigen is defined by reacting with two monoclonal antibodies: The DF3 antibody reacts with an epitope in the TRPAPGS region of the tandem repeat structure and the 111D8 antibody is directed to a carbonhydrate epitope [20]. The MUC-1 gene product is hormonally regulated in endometrial glandular and luminal epithelium with both cell surface associated and secreted isoforms. The abundance of mRNA coding for MUC-1 increases about six fold from the proliferative to the early secretory phase, suggesting a possible dynamic relationship of ovarian steroidogenesis and circulating CA 15-3 levels [3].

In tissues of adult origin, the presence of CA 125 has been demonstrated in the epithelium of the oviduct, in the endometrium and in the endocervix. Epithelial ovarian tumors as well as non-ovarian carcinoma including endometrial, pancreatic, lung, breast, colorectal and other gastrointestinal tumors express it. Its level is elevated in benign conditions like cirrhosis and endometriosis $[2,26]$.

CEA comprises a large family of related cell surface glycoproteins serving as a marker for colorectal, gastrointestinal, lung and breast carcinoma [21,25]. It occurs in slight quantities in intestinal, pancreatic and hepatic tissue of healthy adults. AFP, a marker for hepatocellular and germ cell carcinoma is an estrogen binder. AFP isolated from human cord sera, upon incubation with a molar excess of estradiol, is converted to a form which inhibits estrogen stimulated tissue growth [5,26]. CA 19-9 is a blood group antigen synthesized by normal human pancreatic and biliary ductular cells and by gastric, colonic, endometrial and salivary epithelia. Elevated levels are seen in patients with pancreatic, hepatobiliary, gastric, hepatocellular, colorectal, over and breast carcinoma [26,28].

Cyclical variations of various tumor markers have been investigated previously. However data about healthy women of reproductive age are limited and conflicting. In this study, the time course of five tumor markers namely CEA, AFP, CA 125, CA 15-3, CA 19-9 during follicular and luteal phases of menstrual cycle were analyzed and possible influences of physiological alterations of the hormonal status in regularly ovulating healthy women were evaluated.

\section{MATERIALS AND METHODS}

\section{Subjects}

In this study a group of twenty-three apparently healthy female members of the hospital staff between 21-36 years old (mean \pm SEM; 26.6 \pm 0.88 ) with regular menstrual cycles were studied after their informed consent. Pelvic and abdominal ultrasonography was performed in order to confirm the subjects' health status. Other exclusion criteria were pregnancy, child bearing and any medication, including oral contraceptives. Body mass index (BMI) of the subjects were between 17.6 and $29.5 \mathrm{~kg} / \mathrm{m}^{2}$ (mean $\pm \mathrm{SEM} ; 22.4 \pm 0.74$ ). Fifteen 
of the volunteers were nulliparous and eight had one to two uneventful pregnancies with duration of previous breast feeding between 6-36 months (mean \pm SEM; 19 \pm 4 ). Six of them were Intra Uterine Device (IUD) users. None of them were regularly alcohol consuming but twelve were smokers.

\section{Protocol}

Two blood samples were collected from each subject: one sample on the $7^{\text {th }}$ (range: $6^{\text {th }}-9^{\text {th }}$ ), the other sample on the $21^{\text {st }}$ (range: $20^{\text {th }}-22^{\text {nd }}$ ) day of the menstrual cycle. Repeated samples were collected from three subjects with anovulatory cycles (according to the midluteal progesterone levels) on the consecutive cycle. Blood samples were collected using standard venipuncture technique between 9:30-11:00 a.m. Serum was separated after centrifugation of blood at $+4{ }^{\circ} \mathrm{C}$, $1500 \mathrm{~g}$ for 10 minutes and stored at $-20^{\circ} \mathrm{C}$ until analysis. Luteal and follicular phase assays for each subject were performed on the same run in order to avoid inter-run analytical variation.

\section{Analytical}

Serum LH, FSH, prolactin, estradiol, progesterone and CEA levels were determined with electrochemiluminescence immunoassay method enhanced with magnetic capture on an Elecsys 2010 Immunoassay Analyzer (Boehringer Mannheim, Germany). Serum CA 19-9, CA 15-3, CA 125 and AFP levels were determined with chemiluminescence enzyme immunometric assays on an Immulite Immunoassay Analyzer (Immulite GI-MA ${ }^{\circledR}$, BR$\mathrm{MA}^{\circledR}, \mathrm{OV}^{-M A^{\circledR}}$, AFP assays, DPC, CA, USA). Control sera Precicontrol U1, Precicontrol U2 (Boehringer Mannheim, Germany) for LH, FSH, prolactine, estradiol, progesterone and CEA,
TMCC1013, TMC2013, TMC3013 for AFP, BRCO1001, BRCO2002 for CA 15-3, LGIC10003, LGIC20003 for CA 19-9 and LOMC10010, LOMC20010 for CA 125 assays (DPC, CA, USA) were included in each analytical run. Intra-assay and inter-assay precision performances of the assays were determined on ten replicates in a single run and in four different runs respectively from the samples with the lowest and the highest concentrations of each analyte of the study group. CVs obtained were within $3.2-8.6 \%$ range.

\section{Data Analysis}

Data are usually presented in mean \pm Standard Error of Mean (SEM) unless otherwise stated. Paired differences and the relations of the analytes are evaluated with paired samples $\mathrm{T}$ test and Pearson's bivariate correlation analysis. Comparison of subgroups was performed with Mann Whitney U test. Two tailed p values lower than 0.05 were considerated significant. Statistical analyses and illustrations were performed with SSPS ${ }^{\circledR}$ programs.

\section{RESULTS}

\section{Comparison and Correlation of Follicular and Luteal Phase Tumor Marker Levels}

Twenty-three healthy female subjects with regular menstrual cycles were included in this investigation. Paired differences for midfollicular and midluteal CEA, AFP, CA 19-9 and CA 125 levels of the subjects were (mean \pm SEM) $\quad 0.08 \pm 0.7 \mathrm{ng} / \mathrm{ml}, \quad-0.09 \pm 0.6$ $\mathrm{U} / \mathrm{ml}, 1.24 \pm 1.1 \mathrm{U} / \mathrm{ml}, 0.30 \pm 0.6 \mathrm{U} / \mathrm{ml}$ respectively and the differences were not significant ( $p>0.05)$ but correlations observed between

Table 1

Follicular and luteal phase tumor marker levels, the differences and relations. Values are given in mean \pm SEM

\begin{tabular}{lcccc}
\hline & Midfollicular phase & Midluteal phase & Paired difference & Correlation coefficient \\
\hline CEA (ng/ml) & $1,71 \pm 0,25$ & $1,63 \pm 0,22$ & $0,08 \pm 0,7^{\mathrm{a}}$ & $0,96^{\mathrm{b}}$ \\
AFP $(\mathrm{U} / \mathrm{ml})$ & $1,20 \pm 0,51$ & $1,29 \pm 0,79$ & $-0,09 \pm 0,6^{\mathrm{a}}$ & $0,66^{\mathrm{c}}$ \\
CA 19-9 $(\mathrm{U} / \mathrm{ml})$ & $7,38 \pm 2,07$ & $6,13 \pm 1,85$ & $1,24 \pm 1,1^{\mathrm{a}}$ & $0,85^{\mathrm{b}}$ \\
CA $125(\mathrm{U} / \mathrm{ml})$ & $9,28 \pm 0,83$ & $8,98 \pm 0,71$ & $0,30 \pm 0,6^{\mathrm{a}}$ & $0,72^{\mathrm{b}}$ \\
CA 15-3 $(\mathrm{U} / \mathrm{ml})$ & $19,27 \pm 1,49$ & $26,33 \pm 1,56$ & $-7,06 \pm 1,56^{\mathrm{b}}$ & $0,48^{\mathrm{d}}$ \\
\hline
\end{tabular}

${ }^{\mathrm{a}} \mathrm{p}>0,05 ;{ }^{\mathrm{b}} \mathrm{p}<0,001 ;{ }^{\mathrm{c}} \mathrm{p}<0,005 ;{ }^{\mathrm{d}} \mathrm{p}<0,05$. 


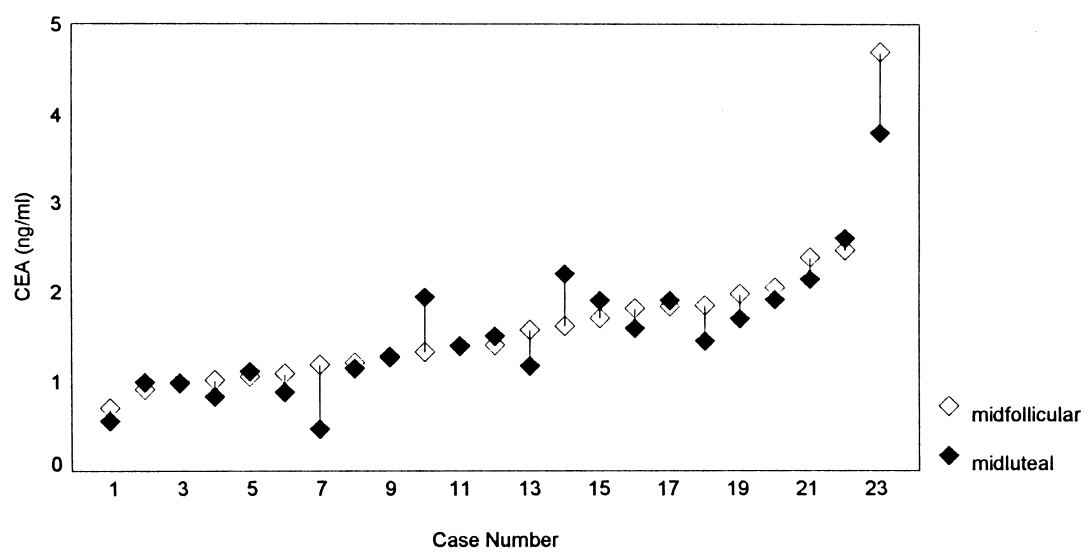

Fig. 1. Midfollicular and midluteal CEA concentrations of the subjects illustrating the phase dependent individual differences. Subjects are arranged according to the midfollicular CEA concentrations in ascending order.

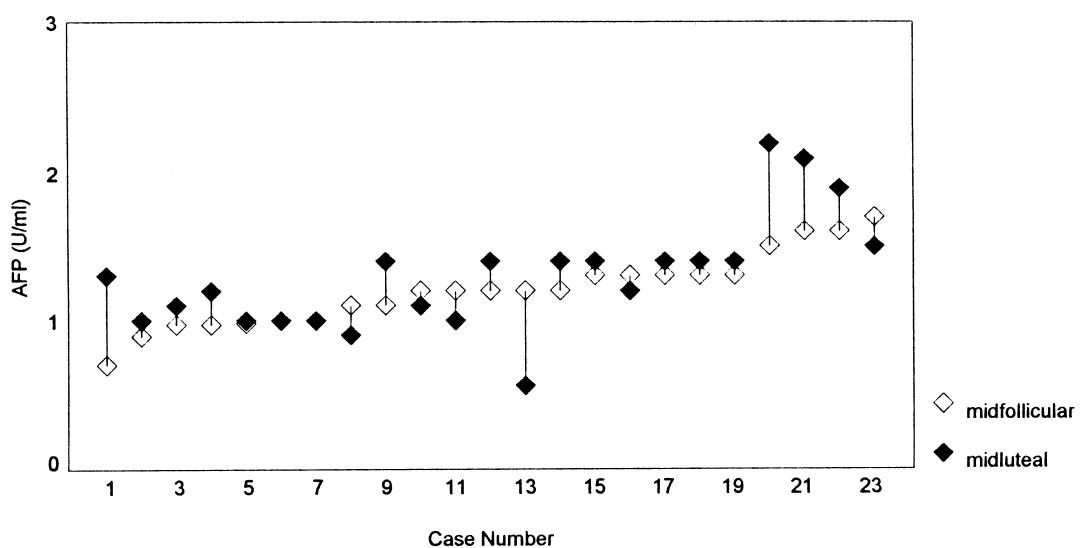

Fig. 2. Midfollicular and midluteal AFP concentrations of the subjects illustrating the phase dependent individual differences. Subjects are arranged according to the midfollicular AFP concentrations in ascending order.

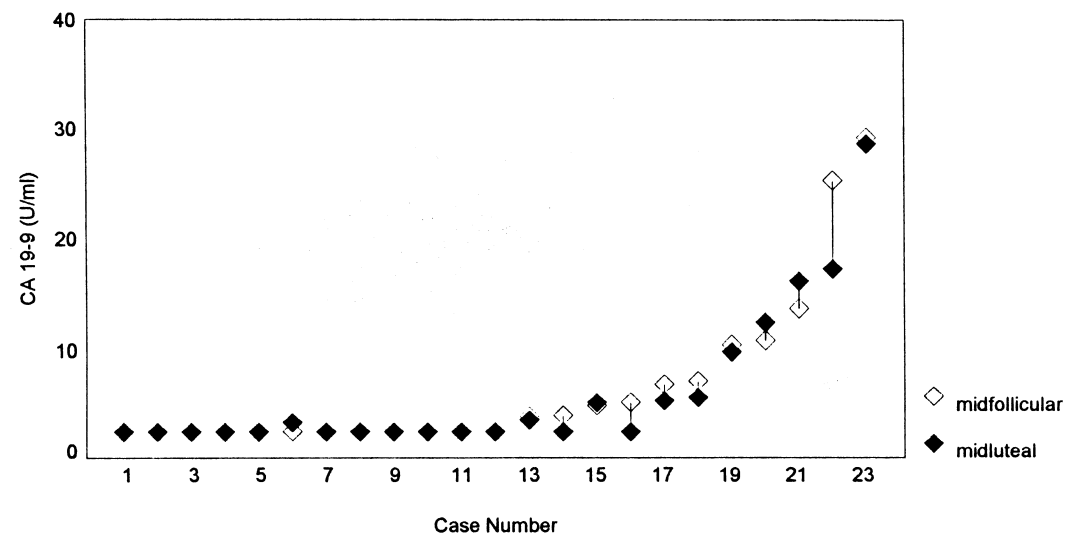

Fig. 3. Midfollicular and midluteal CA 19-9 concentrations of the subjects illustrating the phase dependent individual differences. Subjects are arranged according to the midfollicular CA 19-9 concentrations in ascending order. 


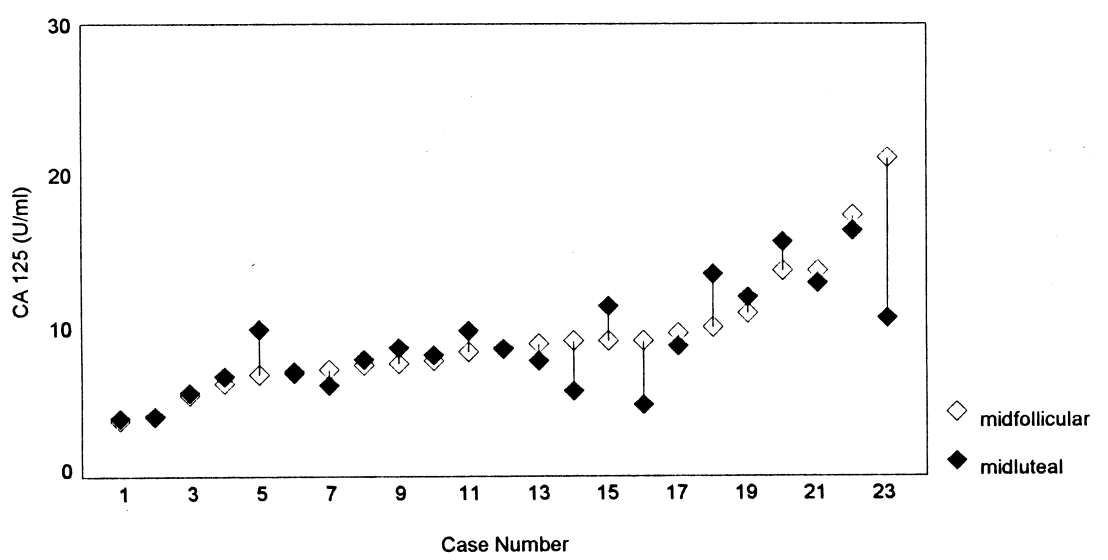

Fig. 4. Midfollicular and midluteal CA 125 concentrations of the subjects illustrating the phase dependent individual differences. Subjects are arranged according to the midfollicular CA 125 concentrations in ascending order.

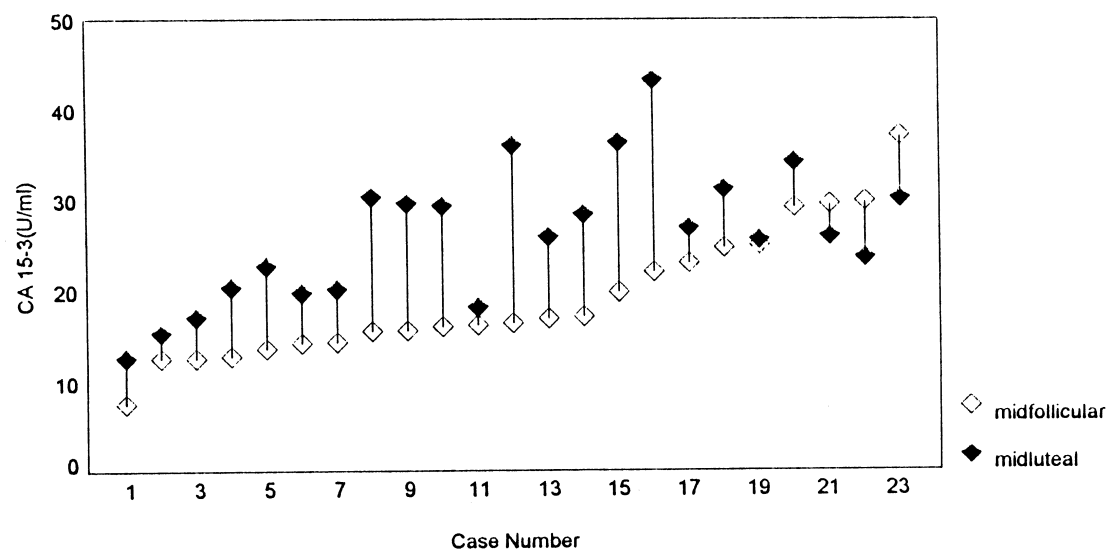

Fig. 5. Midfollicular and midluteal CA 15-3 concentrations of the subjects illustrating the phase dependent individual differences. Subjects are arranged according to the midfollicular CA 15-3 concentrations in ascending order.

tumor marker levels of the two phases were significant; r:0.96, $\mathrm{p}<0.001$ for CEA, r:0.85, $\mathrm{p}<0.001$ for CA 19-9, r:0.72, $\mathrm{p}<0.001$ for CA 125 and r:0.66, p $<0.005$ for AFP (Table 1). Phase dependent differences of CEA, AFP, CA 19-9 and CA 125 for individual subjects are illustrated in Figures 1-4.

On the other hand, paired difference for midfollicular and midluteal CA 15-3 levels of the subjects was significant (mean \pm SEM) $-7.06 \pm$ $1.56 \mathrm{U} / \mathrm{ml} \quad(\mathrm{p}<0.001)$, midfollicular levels $(19.27 \pm 1.49 \mathrm{U} / \mathrm{ml})$ lower than the midluteal levels $(26.33 \pm 1.56 \mathrm{U} / \mathrm{ml})$. Phase dependent differences of CA 15-3 for individual subjects is illustrated in Figure 5. The correlation of CA 153 levels of the two phases was $r: 0.48, p<0.05$ (Table 1).

\section{Correlation of Different Tumor Markers}

CA 19-9 levels of the individuals were significantly correlated to CEA and CA 125 concentrations. Follicular and luteal phase correlations of CA 19-9 with CEA were r:0.65 and $\mathrm{r}: 0.80, \mathrm{p}<0.001$ and with CA 125 were $\mathrm{r}: 0.55$, $\mathrm{p}<0.005$ and $\mathrm{r}: 0.47, \mathrm{p}<0.05$ respectively (Table 2 ). 
Table 2

Correlations of CA 19-9 with CEA and CA 125 during follicular and luteal phases

\begin{tabular}{|c|c|c|c|c|c|}
\hline & & \multicolumn{4}{|c|}{ CA 19-9 (U/ml) } \\
\hline & & \multicolumn{2}{|c|}{ midfollicular } & \multicolumn{2}{|c|}{ midluteal } \\
\hline \multirow[t]{2}{*}{$\overline{\mathrm{CEA}}(\mathrm{ng} / \mathrm{ml})$} & midfollicular & 0.65 & $p<0.001$ & & \\
\hline & midluteal & & & 0.80 & $\mathrm{p}<0.001$ \\
\hline \multirow[t]{2}{*}{ CA $125(\mathrm{U} / \mathrm{ml})$} & midfollicular & 0.55 & $\mathrm{p}<0.005$ & & \\
\hline & midluteal & & & 0.47 & $\mathrm{p}<0.05$ \\
\hline
\end{tabular}

Table 3

Follicular and luteal phase CA 125 concentrations of healthy female subjects partitioned according to BMI. Values are given in mean \pm SEM

\begin{tabular}{lccc}
\hline & Moderately thin (n:3) & Normal (n:14) & Moderately obese (n:4) \\
\hline BMI $\left(\mathrm{kg} / \mathrm{m}^{2}\right)$ & $17-19$ & $19-25$ & $25-30$ \\
Follicular CA 125 (U/ml) & $6.9 \pm 1.6^{\mathrm{a}}$ & $8.7 \pm 0.5$ & $14.9 \pm 2.8$ \\
Luteal CA 125 (U/ml) & $5.7 \pm 1.3^{\mathrm{a}}$ & $9.2 \pm 0.8$ & $12.1 \pm 1.6$ \\
\hline
\end{tabular}

${ }^{\mathrm{a}} \mathrm{p}<0.05$ vs. moderately obese.

\section{Dividing Data into Subgroups}

Tumor marker concentrations of the study group were evaluated after subdividing data according to BMI $(<19,19-25,>25)$, parity (nulliparas, paras), presence of IUD and smoking. Correlation of tumor markers with age and total duration of breast-feeding were also investigated.

Follicular and luteal phase AFP concentrations of the nulliparous subjects (n:15) were $1.2 \pm 0.05$ $\mathrm{U} / \mathrm{ml}$ and $1.4 \pm 0.1 \mathrm{U} / \mathrm{ml}$ respectively and significantly higher than for the parous subjects $(\mathrm{n}: 8)$ $1.04 \pm 0.7 \mathrm{U} / \mathrm{ml}$ and $1.04 \pm 0.1 \mathrm{U} / \mathrm{ml}(\mathrm{p}<0.05)$. Of course, the same results were obtained when the partition criterion was ever breast-feeding but with no correlation to breast-feeding duration.

Both follicular and luteal CA 125 levels were significantly correlated to body mass index (BMI) of the subjects r:0.52, p < 0.05 and r:0.57, $\mathrm{p}<0.005$ respectively. When partitioned as moderately thin, normal and moderately obese, groups were too small to indicate the differences statistically (Table 3).

Other tumor markers were not altered significantly with individual's age, BMI, parity, duration of breast-feeding, presence of IUD or tobacco consumption.

\section{DISCUSSION}

Extensive evidence now indicates that there is a menstrual cycle dependent variability of various tumor markers like CA 125 and PSA [6,32-34]. However data about menstrual cycle and/or hormone dependent variation of serum CA 15-3 of reproductive age healthy women are limited. In this study we observed a significant elevation of midluteal CA 15-3 levels compared to the mid-follicular levels attributable to MUC 1 gene expression in endometrial epithelial cells with increased abundance in the secretory phase of the menstrual cycle, being detectable in uterine fluid at elevated levels in the implantation phase $[3,10,11,23]$. Previously for CASA, a product of the MUC-1 gene, neither a cycle dependent variation nor influence by physiological alterations of the hormonal status was observed [17]. But it should not be assumed that all MUC-1 assays will behave in the same manner. Marked differences in reactivity with CASA and CA 15-3 in patients with ovarian carcinoma were also observed in pregnant women where CASA showed marked elevation and CA 15-3 did not [7]. Although difference observed between luteal and follicular phase CA 15-3 concentrations 
indicate an impact of reproductive hormones on CA 15-3 synthesis or metabolism, it could be associated with hormone receptor status and bioavailibility of hormones rather than with circulating hormone levels $[8,16,27]$. In addition, genotypic and gender associated differences of enzymes involved in steroid hormone metabolism can result in a divergence in hormone efficiency and absolute concentrations [12].

Serum CA 125 is known to be elevated in early pregnancy and during menstruation with the lowest levels at the follicular and periovulatory phases in a substantial proportion of subjects $[25,30]$. However, the reason-effect relationship is not well understood yet. Bonn et al. have suggested the theory that the menstrual rise of CA 125 is due to retrograde menstruation [6]. In several studies impact of ovarian steroidogenesis was not observed in healthy women, nor in women under various hormone treatments and patients with ovarian cancer [15,22,34]. Cyclical changes of CA 125 antigen levels in peritoneal fluid with lower luteal levels were reported but not in the uterine fluid [1,4]. Although our data report no obvious difference between midfollicular and midluteal serum CA 125 levels in healthy women, this does not exclude a rise in early follicular phase, as menstruation of the subjects was not considered. The positive correlation of CA 125 antigen with BMI suggests a possible role of adiposity on CA 125 metabolism. Further studies are necessary to clarify this relationship.

There is a considerable interest in elucidating the normal function of these markers and in determining whether through an altered amount or structure this function is subverted in malignancy. We have recently demonstrated an association of NAT2 genotypes with higher colorectal malignancy incidence (rapid acetylating 4/5B and 4/6A genotypes) and higher serum CEA levels [31]. Anti adhesion properties of CA 15-3 antigen reducing both cell-cell and cellextracellular matrix interactions evoke the possibility that the antigen could promote metastasis. The antigenic determinant for CA 19-9, sialyl $\mathrm{Le}^{\mathrm{a}}$ is involved in the hematogenous metastasis by E-selectin mediated binding of tumor cells to the endothelium [28,29].

The present study did not show an obvious difference for AFP, CEA, CA 19-9, CA 125 during menstrual phases but relatively a small number of subjects were studied. A larger study population, however might have been able to detect smaller differences. Another potential limitation was the timing of the study sessions, which were fixed at $7^{\text {th }}$ and $21^{\text {st }}$ days of the cycle rather than individualized for each subject. Longitudinal comparative studies including more cycles and measurements throughout the cycle are also needed to elucidate whether these alterations are consistent for each individual. Moreover, further studies that determine presence of such a cyclical variation of CA 15-3 in breast carcinoma patients will give more precise interpretation of results in clinical fields.

\section{CONCLUSION}

Our results suggest that the phase of the menstrual cycle may influence serum CA 15-3 concentrations but no impact was observed on other tumor markers investigated. Therefore it appears that biochemical assays of CA 15-3 in premenopausal females need consideration of menstrual cycle synchronization that may lead to a more precise interpretation of results in individual patients. The association of CA 125 levels with BMI suggests a possible role of adipose tissue in CA 125 metabolism.

\section{References}

[1] Abae, M., Gibson, M., Chapitis, J., Riddick, D.H. and Brumsted, J.R. CA-125 levels in humane uterine fluid. Fertil Steril 57, (1992) 531-534.

[2] Abrao, M.S., Podgaec, S., Filho, B.M., Ramos, L.O., Pinotti, J.O. and de Olivera, R.M. The use of biochemical markers in the diagnosis of pelvic endometriosis. Hum. Reprod. 12, (1997) 2523-2527.

[3] Aplin, J.D., Hey, N.A. and Li, T.C. MUC 1 as a cell surface and secretory component of endometrial epithelium: reduced levels in 
recurrent miscarriage. Am. J. Reprod. Immunol. 35, (1996) 261-266.

[4] Barbati, A., Cosmi, E.V., Spaziani, R., Ventura, R. and Montanino, G. Serum and peritoneal fluid CA 125 levels in patients with endometriosis. Fertil Steril 61, (1994) 438-442.

[5] Bennet, J.A., Semeniuk, D.J., Jacobson, H.I. and Murgita, R.A. Similarity between natural and recombinant human alpha-fetoprotein as inhibitors of estrogen-dependent breast cancer growth. Breast Cancer Res. Treat. 45, (1997) 169-179.

[6] Bon, G.G., Kenemans, P., Dekker, J.J., Hompes, P.G., Verstraeten, R.A., van Kamp, G.J., et al. Fluctuations in CA 125 and CA 15-3 serum concentrations during spontaneous ovulatory cycles, Hum. Reprod. 14, (1999) 566-570.

[7] Devine, P.L., McGuckin, M.A., Quin, R.J. and Ward, B.G. Serum markers CASA and CA 15-3 in ovarian cancer: all MUC 1 assays are not the same. Tumour Biol. 15, (1994) 337-344.

[8] Ferguson, A.T. and Davidson, N.E. Regulation of estrogen receptor alpha function in breast cancer. Crit. Rev. Oncog. 8, (1997) 29-46.

[9] Gendler, S.J., Spicer, A.P., Lalani, E.N., Duhig, T., Peat, N., Burchell, J., et al. Structure and biology of a carcinoma associated mucin, MUC 1. Am. Rev. Respir. Dis. 144, (1991) S42-S47.

[10] Hey, N.A. and Aplin, J.D. Sialyl-Lewis $x$ and Sialyl-Lewis a are associated with MUC 1 in human. Gylcoconj. J. 13, (1996) 769-779.

[11] Hey, N.A., Li, T.C., Devine, P.L., Graham, R.A., Saravelos, H. and Aplin, J.D. MUC 1 in secretory phase endometrium: expression in precisely dated biopsies and flushings from normal and recurrent miscarriage patients. Hum. Reprod. 10, (1995) 2655-2662.

[12] Kharasch, E.D., Mautz, D., Senn, T., Lentz, G. and Cox, K. Menstrual cycle variability in midazolam pharmacokinetics. J. Clin. Pharmacol. 39, (1999) 275-280.

[13] Kruitwagen, R.F., Thomas, C., Poels, L.G., Koster, A.M., Willemsen, W.N. and Rolland, R. High CA-125 concentrations in peritoneal fluid of normal cyclic women with various infertilityrelated factors as demonstrated with two-step immunoradiometric assay. Fertil Steril 56, (1991) 863-869.

[14] Lalani, E.N., Berdichevsky, F., Boshell, M., Shearer, M., Wilson, D., Stauss, H., et al. Expression of the gene coding for a mucin in mouse mammary tumor cells can affect their tumorigenicity. J. Biol. Chem. 226, (1991)
$15420-15426$.

[15] Lanzone, A., Fulghesu, A.M., Guida, C., Muscetello, R., Caruso, A. and Mancuso, S. Serum CA 125 levels do not depend on ovarian steroidogenesis. Fertil Steril 54, (1990) 415418.

[16] Mautsatsou, P. and Sekeris, C.E. Estrogen and progesterone receptors in the endometrium. Ann. NY Acad. Sci. 816, (1997) 99-115.

[17] Meisel, M., Römer, T. and Straube, W. Levels of the CASA tumor marker during the menstrual cycle. Zentralbl. Gynakol. 118, (1996) 412-413.

[18] Peat, N., Gendler, S.J., Lalani, N., Duhig, T. and Taylor Papadimitriou, J. Tissue specific expression of a human polimorphicepithelial mucin (MUC 1) in transgenic mice, Cancer Res. 52, (1992) 1954-1960.

[19] Plebani, M., Giacomini, A., Beghi, L., De Paoli, M., Roveroni, G., Galeotti, F., et al. Serum tumor markers in monitoring patients: interpretation of results using analytical and biological variation. Anticancer Res. 16, (1996) 2249-2252.

[20] Price, M.R., Rye, P.D., Petrakou, E., Murray, A., Brady, K., Imai, S., et al. Summary report on the ISOBM TD-4 workshop: analysis of 56 monoclonal antibodies against the MUC 1 mucin. Tumour Biol. 19(Suppl 1), (1998) 1-20.

[21] Rubins, J.B., Dunitz, J., Rubins, H.B., Maddaus, M.A. and Niewoehner, D.E. Serum carcinoembryonic antigen as an adjunct to preoperative staging of lung cancer. J. Thorac. Cardiovasc. Surg. 116, (1998) 412-416.

[22] Shimizu, Y., Fujiwara, H., Akagaki, E., Hirota, K., Kono, M., Irie, T., et al. Significance of CA 125 antigen levels in patients with ovarian cancer. Gan To Kagaku Ryoho 31, (1986) 4652.

[23] Soletermos, G., Nielsen, D., Schioler, V., Skovsgaard, T. and Dombernowsky, P. Tumor markers cancer antigen 15-3, carcinoembryonic antigen, and tissue polypeptide antigen for monitoring metastatic breast cancer during firstline chemotherapy and follow-up. Clin. Chem. 42, (1996) 564-575.

[24] Soletermos, G., Schioler, V., Nielsen, D., Skovsgaard, T. and Dombernowsky, P. Interpretation of results for tumor markers on the basis of analytical imprecision and biological variation. Clin. Chem. 39, (1993) 2077-2083.

[25] Spitzer, M., Kaushal, N. and Benjamin, F. Maternal CA 125 levels in pregnancy and the puerperium. J. Reprod. Med. 43, (1998) 387-392. 
[26] Statland, B.E. and Winkel, P. Neoplasia. In: Clinical Chemistry, Theory, Analysis, Correlation. Kaplan, L.A. and Pesce, A.J. (eds.) Mosby-Year Book Inc., Missouri, (1996) 9831003.

[27] Tseng, L. and Zhu, H.H. Regulation of progesterone receptor messenger ribonucleic acid by progestin in human endometrial stromal cells. Biol. Reprod. 57, (1997) 1360-1366.

[28] Vestergaard, E.M., Wolf, H. and Qrntoft, T.F. Increased concentrations of genotype-interpreted CA 19-9 in urine of bladder cancer patients mark diffuse atypia of the urothelium. Clin. Chem. 44, (1998) 197-204.

[29] Wesseling, J., van der Valk, S. and Hilkens, J. A mechanism for inhibition of E-cadherinmediated cell-cell adhesion by the membrane associated mucin episialin/MUC 1. Mol. Biol. Cell 7, (1996) 565-577.

[30] Whitley, R.J., Meikle, W. and Wattz, N.B. Endocrinology Part 6. In: Tietz Fundementals of Clinical Chemistry. Burtis, C.A. and Ashwood,
E.R. (eds.) WB Saunders Co, USA, (1996) 671684.

[31] Yılmaz, N., Aynacıoğlu, Ş., Erbağc1, A.B., Cascorbi, I. and Roots, I. Implication of arylamine N-acetyltransferase (NAT 2) polymorphsim on levels of tumour markers CEA, AFP, CA 125, CA 19.9, CA 15.3. Biomarkers 4, (1999) 129-134.

[32] Zeimet, A.G., Muller-Holzner, E., Marth, C., Daxenbichler, G. and Dapunt, O. Tumor marker CA 125 in tissues of the female reproductive tract and in serum during normal menstrual cycle. Fertil. Steril. 59, (1993) 1028-1035.

[33] Zarghami, N., Grass, L., Sauter, E.R. and Diamandis, E.P. Prostate specific antigen in serum during the menstrual cycle. Clin. Chem. 43, (1997) 1862-1868.

[34] Zweers, A., De Boever, J., Serreyn, R. and Vandekerckhove, D. Correlation between peripheral CA-125 and ovarian activity. Fertil. Steril. 53, (1990) 409-414. 


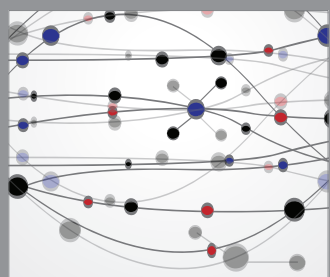

The Scientific World Journal
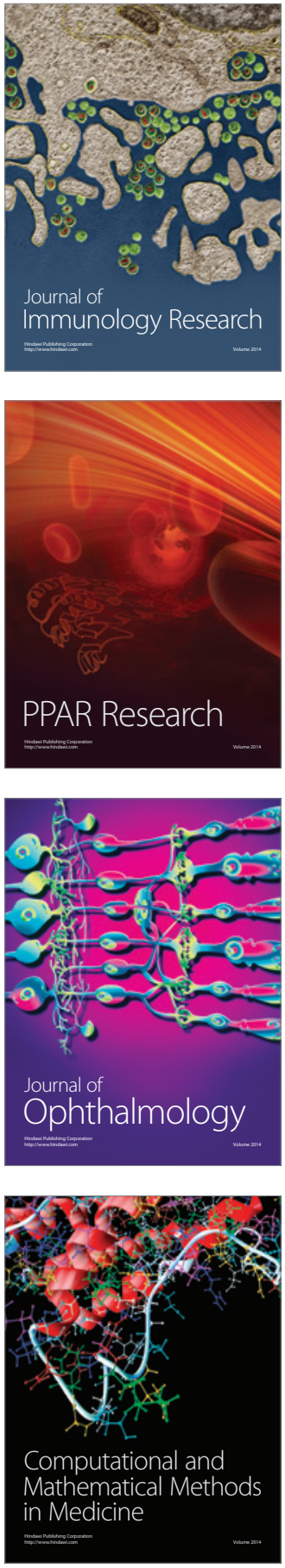

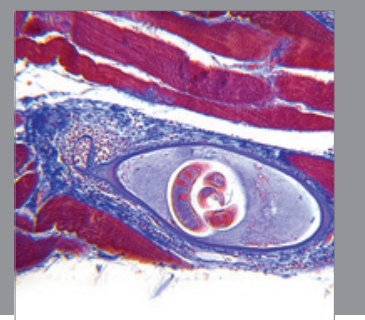

Gastroenterology

Research and Practice
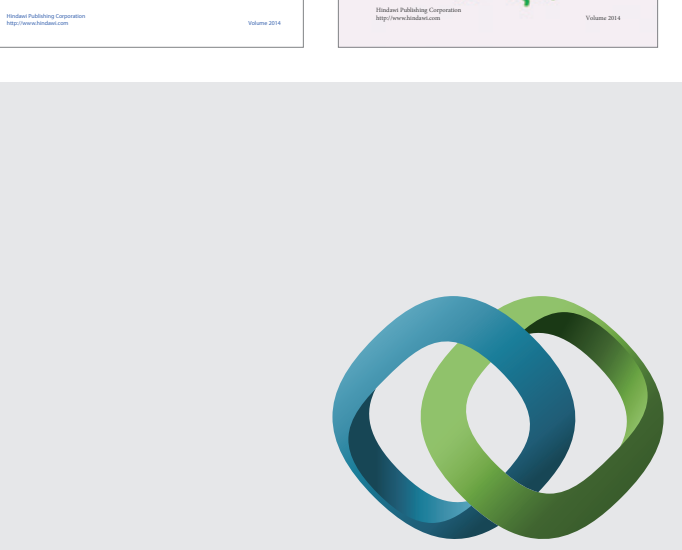

\section{Hindawi}

Submit your manuscripts at

http://www.hindawi.com
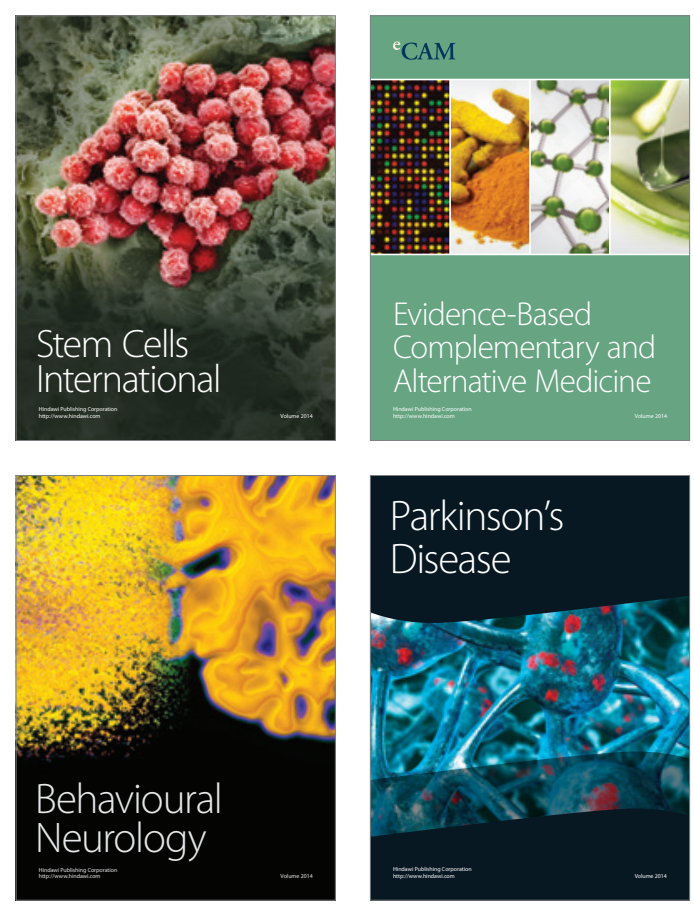

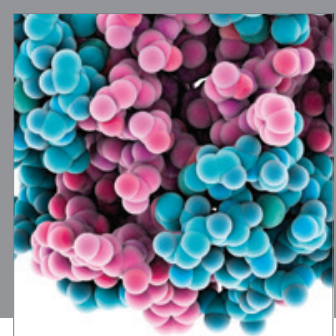

Journal of
Diabetes Research

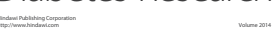

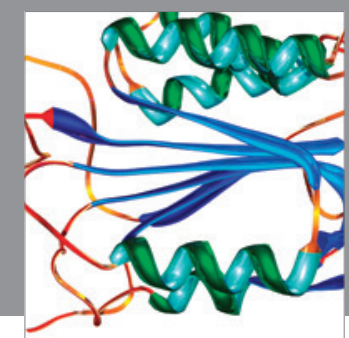

Disease Markers
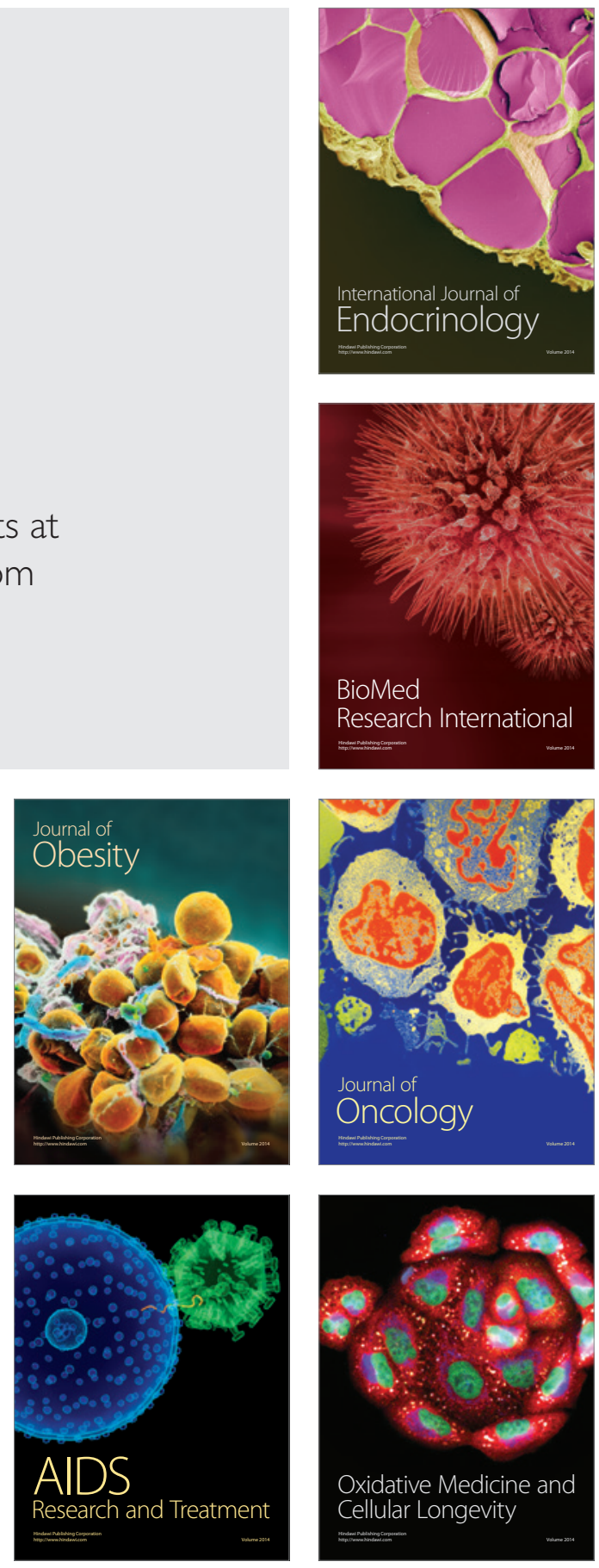